\title{
Automotive Experiences
}

Vol. 3 No.3 (2020) pp. 96-103

p-ISSN: 2615-6202 e-ISSN: 2615-6636

Research Paper

\section{Numerical Study on the Effect of Mean Pressure and Loop's Radius to the Onset Temperature and Efficiency of Traveling Wave Termoacustic Engine}

\author{
Endang Dian Rokhmawati ${ }^{1} \bowtie$, Irna Farikhah ${ }^{2}$, Ummi Kaltsum ${ }^{1}$, Harto Nuroso ${ }^{1}$, \\ Aan Burhanudin ${ }^{2}$, Yuris Setyoadi' ${ }^{2}$, Muhammad Amirudin ${ }^{3}$, Irfan Abd Rahim ${ }^{4}$ \\ ${ }^{1}$ Physics Education, Universitas PGRI Semarang, 50125, Indonesia \\ ${ }^{2}$ Mechanical Engineering, Universitas PGRI Semarang, 50125, Indonesia \\ ${ }^{3}$ Electrical Engineering, Universitas PGRI Semarang, 50125, Indonesia \\ ${ }^{4}$ Manufacturing Engineering, Universiti Malaysia Perlis, 02600, Malaysia
}

endang.rokhma@gmail.com

(d) https://doi.org/10.31603/ae.v3i3.3881

Check for updates Published by Automotive Laboratory of Universitas Muhammadiyah Magelang collaboration with Association of Indonesian Vocational Educators (AIVE)

\begin{abstract}
Article Info

Submitted: 06/08/2020

Revised: 20/09/2020 Accepted: 21/09/2020

Online first: $30 / 09 / 2020$

The thermoacoustic engine can be a device to convert waste heat energy in the engine car become useful energy such as for charging battery in car or Air conditioner of the car. This work can be done by experimentally and numerically. There are some parameters that have an impact on the performance of the engine. They are geometry of the engines, working fluid, and mean pressure. The performance of the engine depends on the efficiency and the heating temperature. In the car, waste heat energy is not high enough. Therefore, we need to utilize the low heating temperature to be converted into useful energy. This study contributes to numerically the effect of mean pressure and loop's radius of the regenerator on the onset temperature and the efficiency of traveling wave thermoacoustic engines. The application that is used to solve numerical problems is fortran95. There are two codings that are used in fortran95. They are stability limits and efficiency codes. The lowest onset temperature that achieved is $153^{\circ} \mathrm{C}$ with efficiency up to $38.1 \%$ that can be reached when the mean pressure is $4.0 \mathrm{MPa}$ and the loop's radius is $5 \mathrm{~cm}$. This result indicated that we can use low heating temperatures from waste heat of engine car to turn on electronics equipment inside the car.
\end{abstract}

Keywords: Mean pressure; Loop's radius; Thermoacoustic engine

\begin{abstract}
Abstrak
Mesin thermoacoustic dapat menjadi alat untuk mengubah energi panas buangan pada mesin mobil menjadi energi yang berguna seperti untuk pengisian aki di mobil atau AC mobil. Pekerjaan ini dapat dilakukan secara eksperimental dan numerik. Ada beberapa parameter yang berdampak pada performa mesin. Mereka adalah geometri mesin, fluida kerja, dan tekanan rata-rata. Performa mesin tergantung pada efisiensi dan suhu pemanasan. Di dalam mobil, energi panas terbuang tidak cukup tinggi. Oleh karena itu, kita perlu memanfaatkan suhu pemanasan rendah untuk diubah menjadi energi yang berguna. Studi ini berkontribusi secara numerik untuk pengaruh tekanan rata-rata dan radius loop regenerator pada suhu awal dan efisiensi mesin termoakustik gelombang berjalan. Aplikasi yang digunakan untuk memecahkan masalah numerik adalah fortran95. Ada dua kode yang digunakan di fortran95. Mereka adalah batasan stabilitas dan kode efisiensi. Onset temperature terendah yang dicapai adalah $153^{\circ} \mathrm{C}$ dengan efisiensi hingga $38,1 \%$ yang dapat dicapai pada tekanan rata-rata 4,0 MPa dan radius loop $5 \mathrm{~cm}$. Hasil ini menunjukkan bahwa kita dapat menggunakan temperatur pemanasan rendah dari limbah panas mesin mobil untuk menyalakan peralatan elektronik pada mobil.
\end{abstract}

Kata-kata kunci: Tekanan rata-rata; Loop radius; Mesin thermoacoustic 


\section{Introduction}

According to the data from the Ministry of Energy and Mineral Resources (ESDM) in the 2019 Indonesia Energy Outlook book (OEI), total energy production in Indonesia tends to decrease in several sectors [1]. Given the depletion of fossil energy in Indonesia and the commitment to reduce greenhouse effect, renewable energy that is more environmentally friendly is needed. The Indonesian Government, through Government Regulation Number 79 of 2014 on the National Energy Policy, has arranged it to overcome this energy crisis. Where the target of the new and renewable energy mix in 2025 is at least $23 \%$ and $31 \%$ in 2050 [2]. Therefore, there is a need for research on the existence of new energy that is environmentally friendly to support energy production in Indonesia, one of which is energy produced from the thermoacoustic process.

Thermoacoustic is a study of the field of interaction between heat and sound, namely about the conversion of thermal energy into sound energy (acoustic) and vice versa [3]. To produce thermoacoustic effects, thermoacoustic devices are needed [4], namely the thermoacoustic engine (prime mover) [5], [6] and thermoacoustic cooler [7], [8], which is often referred to as the heat pump [9]. Several studies have been conducted to improve the efficiency of the performance of thermoacoustic engines. According to Swift and Back exhaust, the use of looped tubes has greater efficiency than using straight tubes [10]. This is because the looped tube is moved by a traveling wave that performs operations with a reversible stirling cycle compared to a straight tube that is done by a standing wave so that it experiences an irreversible process [11].

There are many applications for the thermoacoustic engines. Swift in 1988 demonstrated a thermoacoustic engine [9]. $\mathrm{He}$ was also conducted an investigation about a large thermoacoustic engine. He found that the efficiency of the engine is only $13 \%$ and the heating temperature is $700{ }^{\circ} \mathrm{C}$ [12]. In 2002 Yazaki et. al also had an investigation about a thermoacoustic engine. However, They did not calculate the efficiency of the engine [13]. Moreover, in 2016 and 2017 Farikhah et. al did the calculation of the thermoacoustic engine [14], [15]. In 2017 Farikhah et. al investigated the effect of porosity on the performance of the engine. They found that efficiency is $72 \%$ but the heating temperature is $295{ }^{\circ} \mathrm{C}$ [16]. They found that the efficiency of the engine achieved $75 \%$. However, the heating temperature is still high at $523{ }^{\circ} \mathrm{C}$. Likely, in 2020 Farikhah did the numerical calculation and got the results that the efficiency of the engine is $75 \%$. However, the onset heating temperature is $307^{\circ} \mathrm{C}$ [8]. Experimental research and numerical studies have been carried out to obtain the lowest onset temperature and highest engine efficiency. According to Zang et al, there are several parameters in order to get the lowest heating temperature and highest engine efficiency, it is mean pressure [12], stack's radius [13], stack's length [14], etc. All of the investigations done by other researchers the heating temperature is still high which is impossible for utilizing waste heat from car engines since the waste heat of the engine car is lower than $200{ }^{\circ} \mathrm{C}$. Therefore, in our study, we want to focus on finding the low onset heating temperature while keeping the efficiency still high.

Based on those problems, this research carried out by examining numerically to determine the lowest onset temperature and highest efficiency by variating the mean pressure and the loop's radius on traveling wave thermoacoustic engine by looped tube.

\section{Method}

\subsection{Calculation Model}

The scheme of the thermoacoustic engine system which is the calculation model in this study is shown in Figure 1. The thermoacoustic engine used in this study uses a looped tube that is generated by travelling wave. Components in this thermoacoustic machine include: a loop, a hot-heat exchanger, an ambient heat exchanger, and a thermal buffer tube. As a control variable, the length of the circular pipe $L_{\text {Loop }}$ set of 2.8 meters, the narrow channel radius of the regenerators $r_{s} 0.7 \mathrm{~mm}$, the length of the loop $L_{\text {stack }} 7 \mathrm{~cm}$, the porosity of the loop $p_{s} 09$, and the working gas used is helium with a pressure of 501 $\mathrm{KPa}$.

The loop's radius is denoted as $R_{\text {Loop }}$. In this calculation, the mean pressure $P_{m}$ and the radius 




Figure 1. Schematic of a thermoacoustic engine system

of the loop $R_{\text {Loop }}$ are used as parameters to find the low heating temperature and efficiency of the thermoacoustic engine. The temperatures at the hot-heat exchanger and ambient-heat exchanger are denoted as $T_{H}$ and $T_{A}$, respectively. In numerical calculations, the $T_{A}$ value is determined according to room temperature, which is $301 \mathrm{~K}$ or $28^{\circ} \mathrm{C}$. As for $T_{H}$, it is determined by calculating the stability limit, where the independent variables are used one by one to get the lowest heating power.

\subsection{Calculation Method}

In computational calculations, the acoustic approximation equation is used by Rott [15] is used as presented in Eq. (1) and Eq. (2).

Where $P$ shows the oscillation pressure fluctuation, $U$ as the flow velocity fluctuation, $\omega$ is the angular frequency of the sound wave, $\rho_{m}$ is the average density, $A$ is the pipe cross-sectional area, $\gamma$ is the specific heat ratio, $T_{m}$ is the average gas temperature, $P_{m}$ is the mean pressure, and $\sigma$ is the Prandtl stipulation number. While, $\rho_{m}, \gamma$ and $\sigma$ depends on $T_{m}$ and $x$ is the coordinate axis along the pipe [16].

When $\frac{d T_{m}}{d x}=0$, Eq. (2) can be solved analytically. This is because $\rho_{m}, \gamma, \chi_{a}, \chi_{v}$ and $\sigma$ are not bound to $x$, so that the second form on the right side of Eq. (2) is lost. When the oscillator pressure and volume velocity at the point $x_{0}$ are notated by $P_{0}$ and $U_{0}$, the solution can be solved by the Eq. (3).

When $\frac{d T_{m}}{d x} \neq 0$, the solutions for Eq. (2) will be difficult to solved by analytics, so it have to computationally integrated. The solutions will be solved by fourth-order Runge-Kutta method as presented in Eq. (4).

$$
\frac{d P}{d x}=-\frac{1}{A} \frac{i \omega \rho_{m}}{1-\chi_{\alpha}} U
$$

$\frac{d U}{d x}=-\frac{i \omega A\left[1+(\gamma-1) \chi_{\alpha}\right]}{\gamma P_{m}} P+\frac{\chi_{\alpha}-\chi_{v}}{\left(1-X_{v}\right)(1-\sigma)} \frac{1}{T_{m}} \frac{d T_{m}}{d_{x}} U$

$\frac{d}{d x}\left(\begin{array}{l}P(x, t) \\ U(x, t)\end{array}\right)=C(x)\left(\begin{array}{l}P(x, t) \\ U(x, t)\end{array}\right)$, then

$$
C(x) \equiv\left(\begin{array}{cc}
0 & -\frac{1}{A} \frac{i \omega \rho_{m}}{1-\chi_{v}} \\
-\frac{i \omega A\left[1+(\gamma-1) \chi_{a}\right]}{\gamma P_{m}} & \frac{\chi_{a}-\chi_{v}}{(1-\sigma)\left(1-\chi_{v}\right)} \frac{1}{T_{m}} \frac{d T_{m}}{d x}
\end{array}\right)
$$




$$
\begin{aligned}
& \left(\begin{array}{l}
P(x+\Delta x, t) \\
U(x+\Delta x, t)
\end{array}\right)=\left(E+\Delta x C^{\prime}(x)\right)\left(\begin{array}{l}
P(x, t) \\
U(x, t)
\end{array}\right) \\
& C^{\prime}(x)=\frac{1}{6}\left(R K_{1}+2 R K_{2}+2 R K_{3}+R K_{4}\right) \\
& R K_{1}=C(x) \\
& R K_{2}=C(x+\Delta x / 2)\left(E+\frac{\Delta x}{2} R K_{1}\right) \\
& R K_{3}=C(x+\Delta x / 2)\left(E+\frac{\Delta x}{2} R K_{2}\right) \\
& R K_{4}=C(x+\Delta x)\left(E+\Delta x R K_{3}\right)
\end{aligned}
$$

Here $E$ is a unit matrix, hence:

$$
\begin{aligned}
& \left(\begin{array}{l}
P(x, t) \\
U(x, t)
\end{array}\right)=M_{11}\left(x, x_{0}\right)\left(\begin{array}{l}
P_{0}\left(x_{0}, t\right) \\
U_{0}\left(x_{0}, t\right)
\end{array}\right) \\
& M_{11}\left(x, x_{0}\right) \equiv\left(E+\Delta x C_{n-1}^{\prime}\right)\left(E+\Delta x C_{n-2}^{\prime}\right) \ldots\left(E+\Delta x C_{1}^{\prime}\right)\left(E+\Delta x C_{0}^{\prime}\right)
\end{aligned}
$$

Where $n$ is a partition number, which has the meaning of being the separator number between $x_{0}$ and $x, \Delta x$ is defined as $\left(x-x_{0}\right) / n$, and $C_{j}^{\prime}$ shows $C^{\prime}$ in $x=x_{0}+j \Delta x$.

Ueda explained a method for calculating the stability of the oscillation constant limit gas for straight tube and looped tube. This is importance to obtain the onset heating temperature to produced acoustic power. Then the power can be used for the other energy for example for thermoacoustic refrigeration/ Air Conditioner or thermoacoustic electric power generation. On the graph shown in Figure 2, the temperature distribution along the pipe is shown and the temperature distribution is close to the loop.

From Figure 2, it is known that the transfer matrix $T_{m}$ is kept constant at $x=-3 L / 8$ to $X_{2}$. The transfer matrix $M_{I, 1}$ is calculated using $M_{1}$. The ambient-heat exchanger transfer matrix $M_{I, c h x}$ is calculate from $x=-X_{2}-X_{1}$, and the hot-heat exchanger transfer matrix $M_{I, h h x}$ which is represented by a range of regions $x=X_{1}$ up to $X_{2}$, and a transfer matrix in the region $x=X_{3}$ up to $5 L / 8$ that symbolized $M_{I, 2}$.

$T_{m}$ express constant except in the range of the loop $x=-X_{1}$ up to $X_{1}$ and thermal buffer tube from $X_{2}$ up to $X_{3}$, which are then denoted in a row with $M_{I I, S}$ and $M_{I I, t b}$. Equation (6) can be used to calculate the transfer matrix $M_{I I, S}$ and $M_{I I, t b}$. The partition number is $n=100$, because it's have been research that the calculation of the stability limit with the partition number $n=100,200$, and 400 shows the same value. Using all available transfer matrices, we can calculate the total matrix system $M_{\text {all }}$ :

$M_{\text {all }}=M_{I, 2} M_{I I, t b} M_{I, h h x} M_{I I, S} M_{I, c h x} M_{I, 1}$
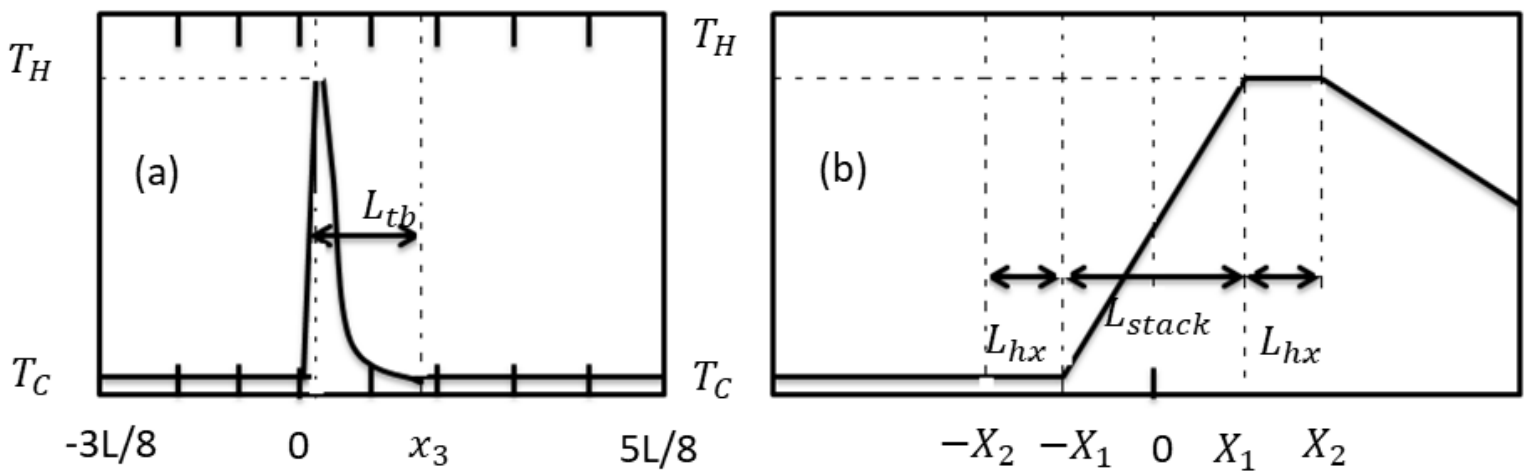

Figure 2. Temperature distribution: (a) along the pipe and (b) close to the loop 
Using all total matrix system $M_{\text {all }}$, the oscillation pressure $P_{E, A}$ and oscillation velocity $U_{E, A}$ have a similar relations in $x=-3 L / 8$ to the $P_{E, A}$ and $U_{E, A}$ when $x=5 L / 8$, so:

$$
M_{\text {all }}\left(\begin{array}{l}
P_{E, A} \\
U_{E, A}
\end{array}\right)=\left(\begin{array}{l}
P_{E, B} \\
U_{E, B}
\end{array}\right)
$$

In looped tube, there is a slight difference in calculating the stability of the limit. When the $P_{E, A}$ and $U_{E, A}$ at $x=-3 L / 8$ same with position at $x=$ $5 L / 8$. Thus, Eq. (8) can be expressed by:

$$
M_{\text {all }}\left(\begin{array}{l}
P_{E, A} \\
U_{E, A}
\end{array}\right)=\left(\begin{array}{l}
P_{E, A} \\
U_{E, A}
\end{array}\right)
$$

The solution for $\left(P_{E, A}, U_{E, A}\right)$ will not be zero if the determinant of the matrix $\left(M_{\text {all }}-E\right)$ is zero, or can be specified as:

$$
\left(m_{11}-1\right)\left(m_{22}-1\right)-m_{12} m_{21}=0
$$

Here $\mathrm{E}$ denotes the unit matrix of $m_{i j}$ which is the element of $M_{\text {all }}$. Thus, Eq. (10) can determine the stability limit conditions of the spontaneous gas oscillation induced in the looped tube thermoacoustic engine [17]. Then, we can find the onset heating temperature.

In understanding thermoacoustic devices, we need to describe the power that connected with thermoacoustic wave propagation [18]. This is because an acoustic wave causes pressure, density, and temperature changes in a thermoacoustic device, which is very necessary for energy conversion between heat and work [19]. In his study, Rott formulated:

$$
H=\dot{W}-\dot{Q}
$$

As a mathematical calculation, we need to calculate the acoustic power equation $\dot{W}[W]$, acoustic heat power $\dot{Q}[\mathrm{~W}]$ [18] which is indicated by oscillation pressure $P$ and the average of crosssectional area $A$ of the oscillation velocity $U$. The equation becomes [20]:

$$
\dot{W}=I A=\frac{1}{2} \operatorname{Re}[P \widetilde{U}]
$$

$$
\begin{aligned}
\dot{Q}=\frac{1}{2} \operatorname{ARe}\left[\operatorname{PU}\left(\frac{\widetilde{\chi_{v}}-\chi_{\alpha}}{(1+\sigma)\left(1-\chi_{v}\right)}\right)\right] & \\
& -A \frac{\rho_{m} c_{p}|U|^{2}}{2 \omega\left(1-\sigma^{2}\right)\left|1-\chi_{v}\right|^{2}} \operatorname{Im}\left(\chi_{\alpha}\right. \\
& \left.+\sigma \tilde{\chi}_{v}\right) \frac{d T_{m}}{d x}
\end{aligned}
$$

Equation (12) and Eq. (13) can be substituted into Eq. (11) to become Eq. (14).

$$
\frac{d T m}{d x}=\frac{\dot{\mathrm{H}}-\frac{A}{2} \operatorname{Re}\left[P \widetilde{U}\left(1-\frac{\widetilde{\chi_{v}}-\chi_{\alpha}}{(1+\sigma)\left(1-\chi_{v}\right)}\right)\right]}{A \frac{\rho_{m} c_{p}|U|^{2}}{2 \omega\left(1-\sigma^{2}\right)\left|1-\chi_{v}\right|^{2}} \operatorname{Im}\left[\chi_{\alpha}+\sigma \tilde{\chi}_{v}\right]}
$$

In his paper, Yazaki explained that when the onset heating temperature $T_{H}$ exceeds the critical temperature, the gas will be spontaneous oscillating [21]. This means, acoustic waves will pass through a circular tube and transfer energy spontaneously. In this case, the acoustic power generated from the spontaneous oscillation $\Delta \dot{W}_{E, A}$ is an input for the ambient-heat exchanger and the power booster in the loop's machine. In addition, acoustic power $\Delta \dot{W}_{E, A}$ can be generated from the number of loop engine heat exchangers [22]. So, the additional acoustic power on the engine loop can be formulated into:

$$
\Delta \dot{W}_{E}=\dot{W}_{E, H}-\dot{W}_{E, A}
$$

Furthermore, to increase acoustic power, the hot-heat exchanger needs to supply acoustic thermal power $\dot{Q}_{H}$. Thus, the efficiency of the engine loop can be written in the equation:

$$
\eta_{E 1}=\frac{\Delta \dot{W}_{e}}{\dot{Q}_{H}}
$$

In this study, we used the efficiency that depend by onset heating temperature. The equation is written bellow [22]:

$$
\eta_{E 2}=\frac{\eta_{e}}{\eta_{\text {carnot }}}
$$

Overall, the calculations for the total engine efficiency are presented in Figure 3. 




Figure 3. Flow chart for evaluating efficiency of the engine $\left(\eta_{e}\right)$

\section{Resuts and Discussion}

The results of this study are presented in the graphs relations of $T_{H}$ and $\eta_{E 2}$ for variations in mean pressure and loop's radius in Figure 4 and Figure 5.

Figure 4 shows the lowest onset temperature $T_{H}$ has decreased dramatically starting from mean pressure $P_{m}$ of $0.5 \mathrm{MPa}-2 \mathrm{MPa}$, and tends to decrease constantly from 2 - $4 \mathrm{MPa}$. When $R_{\text {Loop }}$ got increased, the $T_{H}$ shows gradually decreasing. From this graph it can be seen that the lowest onset temperature is obtained in $153{ }^{\circ} \mathrm{C}$ when $P_{m}$ is $4.0 \mathrm{MPa}$ and $R_{\text {Loop }}$ is $5 \mathrm{~cm}$. $T_{H}$ is influenced by the phase of the wave $\phi$. This can be observed by Figure 6.

According to Figure 6, when $R_{\text {Loop }}=5 \mathrm{~cm}$ and $P_{m}=4.0 \mathrm{Mpa}$, the lowest phase $\phi$ is generated at $50,7^{\circ}$. This is the same as the graph in Figure 4, which also $T_{H}$ reaches the lowest value in that position. This phase is inversely proportional to the acoustic power produced. The lowest $\phi$, will produce the highest acoustic power $\Delta W$. This is in accordance with the equation by Ueda [11]:

$$
\frac{\Delta W}{\dot{W}} \cong \frac{\Delta P}{P}+\frac{\Delta U}{U}-\tan \phi . \Delta \phi
$$

In Figure 5, the efficiency decreases linearly as the decreases of $P_{m}$. On the graph it can be observed, efficiency also decreases as the loop's radius $R_{\text {Loop }}$ decreases. From the graph, it can be seen that the highest efficiency is obtained when $P_{m}$ is $0.5 \mathrm{MPa}$ and $R_{\text {Loop }} 1 \mathrm{~cm}$, which is equal to $88.8 \%$.

Figure 4 and Figure 5 show that to achieve high efficiency, high onset temperatures are also needed. When $P_{m}$ is $0.5 \mathrm{MPa}$ and $R_{\text {Loop }} 1 \mathrm{~cm}$, the highest efficiency is obtained, but the required onset temperature is also high, reaching $2295{ }^{\circ} \mathrm{C}$. Conversely, when the $P_{m}$ is $4 \mathrm{MPa}$ and $R_{\text {Loop }} 5 \mathrm{~cm}$, the lowest heating temperature is obtained in 153 ${ }^{\circ} \mathrm{C}$, but the resulting efficiency is not too large, only $38.1 \%$. Select the proper parameters is needed to get the highest efficiency or to get the lowest onset temperature. In this research, the most properest to execute is at $P_{m}$ of $2 \mathrm{MPa}$ and $R_{\text {Loop }} 5 \mathrm{~cm}$. This election is not solely without reason because is produce $T_{H} 174{ }^{\circ} \mathrm{C}$ wich including in low grade waste heat [23] the most generated from industrial activity [24].

In the calculation $\eta_{E 2}$, the actual efficiency of a machine $\eta_{E 1}$ is compared with the carnot efficiency $\eta_{C}$ according to the Eq. (15). The higher the actual efficiency value and the lower the carnot efficiency value, it will reach its maximum $\eta_{E 2}$. The relation of $\eta_{E 1}, \eta_{C}$ and $P_{m}$ are shown in Figure 7 and Figure 8, it can be seen both of $\eta_{E 1}$ and $\eta_{C}$ reach their maximum values when they are used $P_{m} 0.5 \mathrm{MPa}$ and $R_{\text {Loop }} 1 \mathrm{~cm}$. This is evidence of involvement $\eta_{E 1}$ and $\eta_{C}$ to $\eta_{E 2}$. 




Figure 4. Graph $T_{H}$ as a function of $P_{m}$ and $R_{\text {Loop }}$

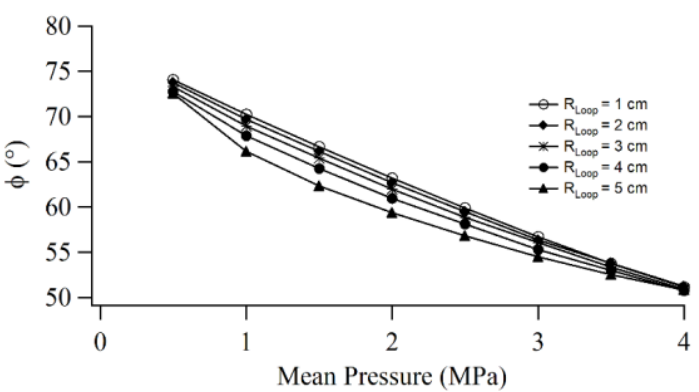

Figure 6. Graph of $\phi$ as functions of $P_{m}$ and $R_{\text {Loop }}$

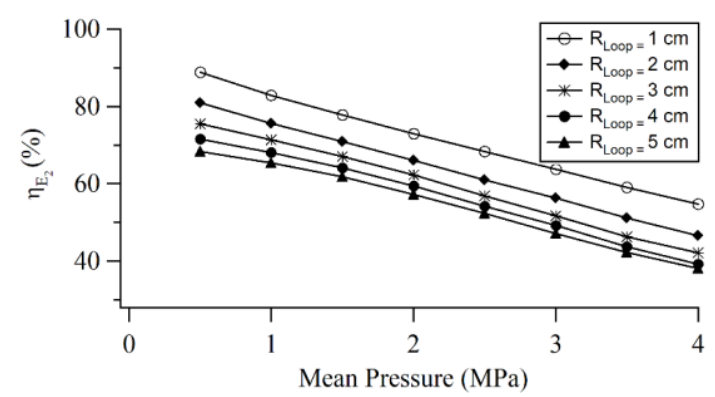

Figure 5. Graph $\eta_{E 2}$ as a function of $P_{m}$ and $R_{\text {Loop }}$

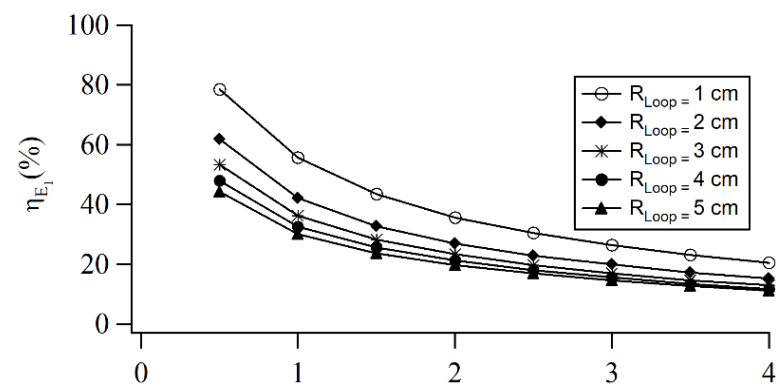

Figure 7. Graph $\eta_{E 1}$ as a function of $P_{m}$ and $R_{\text {Loop }}$



Figure 8. Graph $\eta_{C}$ as a function $P_{m}$ and $R_{\text {Loop }}$

\section{Conclusion}

In this study, the lowest onset temperature is $T_{H} 153^{\circ} \mathrm{C}$ which is more affordable for waste heat in the engine car to be converted to another useful energy. This temperature is obtained when the mean pressure $P_{m} 4 M P a$ is used and the radius of the loop is $5 \mathrm{~cm}$. With this onset temperature, the efficiency of the engine produced is $38 \%$. In this study, it can be concluded that there is an effect of mean pressure and loop's radius on the of onset heating temperature and thermoacoustic engine efficiency. The engine model gives guidence for researchers who work experimentally to select parameter for getting low heating temperature.

\section{Author's Declaration}

\section{Authors' contributions and responsibilities}

The authors made substantial contributions to the conception and design of the study. The authors took responsibility for data analysis, interpretation and discussion of results. The authors read and approved the final manuscript.

\section{Funding}

This research is funded by LPPM Universitas PGRI Semarang.

\section{Availability of data and materials}

All data are available from the authors.

\section{Competing interests}

The authors declare no competing interest.

\section{Additional information}

No additional information from the authors.

\section{References}

[1] Suharyati, S. H. Pambudi, J. L. Wibowo, and N. I. Pratiwi, "Outlook Energi Indonesia," Jakarta, 2019.

[2] Government Regulation of the Republic of Indonesia Number 79 of 2014 on National Energy Policy.

[3] I. Setiawan, P. Murti, W. N. Achmadin, and 
M. Nohtomi, "Pembuatan dan Pengujian Prime Mover Termoakustik Tipe Gelombang Tegak," in Proceeding Seminar Nasional Tahunan Teknik Mesin XIV (SNTTM XIV), 2015.

[4] G. A. I. Varian, "Karakteristik Termoakustik Berdasarkan Variasi," Universitas Indonesia, 2011.

[5] S. W. Utami, I. Farikhah, N. Khoiri, S. Patonah, and U. Kaltsum, "Kajian Numerik Pengaruh Jari-Jari Stack terhadap Pemanasan Suhu Rendah Mesin Termoakustik Gelombang Berjalan," in Seminar Nasional Lontar Physics Forum, 2019, pp. 23-30.

[6] S. W. Utami, I. Farikhah, N. Khoiri, S. Patonah, U. Kultsum, and S. Suciati, "Numerical study of the influence of radius stack on the low heating temperature and efficiency of traveling wave thermoacoustic engine," JPhCS, vol. 1464, no. 1, p. 12012, 2020.

[7] I. Farikhah, "The effect of mean pressure on the performance of a single-stage heat-driven thermoacoustic cooler," International Journal of Low-Carbon Technologies, 2020.

[8] I. Farikhah et al., "Thermoacoustic design using stem of goose down stack," in AIP Conference Proceedings, 2012, vol. 1474, no. 1, pp. 283-286.

[9] G. W. Swift, "Thermoacoustic Engines," Journal of Accoustical Society of America, vol. 84, no. 4, pp. 1145-1180, 1988.

[10] S. Backhaus and G. W. Swift, "A thermoacoustic-Stirling heat engine: Detailed study A thermoacoustic-Stirling heat engine: Detailed study," Journal of Accoustical Society of America, vol. 107, no. 6, pp. 3148-3166, 2000.

[11] Y. Ueda, T. Biwa, U. Mizutani, and T. Yazaki, "Experimental studies of a thermoacoustic Stirling prime mover and its application to a cooler," Acoustical Society of America, vol. 115, no. 3, pp. 1134-1141, 2004.

[12] X. Zang, J. Chang, S. Cai, and J. Hu, "A multistage travelling wave thermoaccoustic engine driven refigerator and operation features for utilizing low grade energy," Energ Convers Manage, vol. 114, no. 224, p. 33,
2016.

[13] S. W. Utami, "Kajian Numerik Pengaruh JariJari Stack Terhadap Suhu Pemanasan Rendah Dan Efisiensi Mesin Termoakustik Tipe Gelombang Berjalan," Universitas PGRI Semarang, 2019.

[14] K. Rahmatunisa, “Kajian Numerik Pengaruh Panjang Dan Diameter Stack Terhadap Suhu Pemanasan Rendah Dan Efisiensi Mesin Termoakustik Tipe Gelombang Berjalan," Universitas PGRI Semarang, 2019.

[15] N. Rott, "Damped and Thermally Driven Acoustic Oscillations in Wide and Narrow Tubes," Z Angew Math Phys, vol. 20, pp. 230243, 1969.

[16] T. Yazaki, A. Tominaga, and Y. Narahara, "Experiments on thermally driven acustics oscillations of gaseous helium," Low Temperature Physics, vol. 41, pp. 45-60, 1980.

[17] Y. Ueda and C. Kato, "Stability analysis of thermally induced spontaneous gas oscillations in straight and looped tubes," Journal of Accoustical Society of America, vol. 124, no. 2, pp. 851-858, 2008.

[18] T. Rossing, Springer handbook of acoustics. Springer Science \& Business Media, 2007.

[19] N. Rott, "Thermally driven acoustic oscillations. Part III: Second-order heat flux," $Z$ angew Math Phys, vol. 26, pp. 43-49, 1975.

[20] I. Farikhah and Y. Ueda, "Numerical Calculation of the Performance of a Thermoacoustic System with Engine and Cooler Stacks in a Looped Tube," Applied Sciences, vol. 7, pp. 1-14, 2017.

[21] T. Yazaki, T. Biwa, and A. Tominaga, "A pistonless Stirling cooler," Applied Physics Letters, vol. 80, no. 1, 2002.

[22] I. Farikhah, "Optimization of a heat-driven thermoacoustic cooler in a looped tube with two stacks," Tokyo University, 2018.

[23] I. Johnson, W. T. Choate, and A. Davidson, "Waste heat recovery: technology and opportunities in US Industry," 2008.

[24] C. Haddad, C. Perilhon, A. Danlos, and M. X. Francois, "Some efficient solutions to recover low and medium waste heat: competitivness of the thermoacoustic technology," in Energy Procedia, 2014, pp. 1056-1069. 